\title{
Virtual Laboratory Implementation to Support High School Learning
}

\author{
Arief Hidayat \\ Information System Department \\ STIMIK Pro Visi \\ Semarang
}

\author{
Victor Gayuh Utomo \\ Computer Science Department \\ STIMIK Pro Visi \\ Semarang
}

\begin{abstract}
Learning activities are not limited to the delivery of theory content and evaluation, but they also include some experiment activity in laboratory. Some subjects require experiments activity in the laboratory, i.e. Biology, Mathematics, Chemistry and Physics. Those subjects demand the educational institution, high school in this occasion, to provide facilities and infrastructure in the form of laboratory equipment in order to support experiment activities. However, the experiment activity currently conducted in laboratory not yet suffice the need of student to learn independently. An additional experiment activity is needed, in such way that takes time other than learning hour and can be done independently. Laboratory access must not limited to attending school laboratory physically, in a sense that nonphysical laboratory such as virtual laboratory may also be included. This research result an implementation of virtual laboratory in the form of computer application that is available anybody for experiments with affordable cost at any given time and place as long as connected to main server provider.
\end{abstract}

\section{Keywords}

Virtual laboratory, high school, learning

\section{INTRODUCTION}

Laboratory experiment and other form of experiment in learning are expected to assist student to acquire the technical ability. The experiments should be an important source of learning in order to better understanding both in concepts and theories. Experiments may also improve students' creative thinking.

According to Peraturan Pemerintah (Government Regulation) No. 19 of 2005 on Standar Nasional Pendidikan (National Education Standard) article 19 paragraph 1, suitable learning process is required to improve the ability of creative thinking. The regulation explains that learning process in educational institution organized in such manners as interactive, inspiring, fun, challenging, give student motivation to take active role and provide enough space for innovation, creativity and independence related to students' talent, interest, and physical and psychological development.

The main disadvantage in conventional learning is limited learning time availability. Classroom distribution and provision and also teacher schedule heavily impact learning activities. Involvement of many stakeholders, especially teachers and students, makes learning activities need a shared commitment in terms of time and place. Such condition put constraint which limit the flexibility of time avilability for learning activities.[1]
The reality of learning activities shows the fact that many school don't have the required instruments / equipment to conduct laboratory experiment. It is a result of the high laboratory operational cost. Only a few students has the opportunity to develop thinking ability because of the lack of lab experiments. Many students just received an explanation from the teacher alone without performing experiments.

Another cause that can inhibit the creative potential in the formal educational environment is the learning process which is mostly teacher-centered. Teacher explains the subject with a lecture then give exercises and assignments while the students become information recipient. As a result, the students merely copying what the teacher says and asks, without further explanation and understanding. The students assume that it is enough to work the study as exampled. It causes the students' lack of interest and lack of curiosity which not good for improvement of creative thinking skills [2].

The ability of creative thinking is a person's ability to create something new, in the form of idea or work, that relatively different from what has gone before. In this context, something new doesn't necessarily a brand new product $/$ creation, even though the end result may look totally new, it may be a result of combining two or more concepts that may already exist in the past [3].

Interest, according Slameto [4], means a better sense of joy and a sense of attachment to a thing or activity, without being told. In other words, interest is a sense of a more happy in oneself in giving greater attention to a particular object.

In general, many students consider that science subjects (Biology, Mathematics, Chemistry and Physics) a daunting and tedious, resulting many students have no interest in understanding and mastering basic concepts in science subjects. To overcome the difficulties, the teachers are expected to be able to present the science subjects more interesting and creative. Hopefully, the students may rid the wrong prejudice that science subjects is difficult for them. To present science subjects more attractive, teachers must have the ability to develop learning methodology or model and utilize learning media in such way that raise students' interest and achieve learning objectives well.

Currently, many high schools hold learning activities both theory and practical conventionally. Distance learning as a form to support independent learning activities not yet effective moreover with the lack independent experiment in laboratory. Students only fixated on learning activities in the classroom and experimental activities in laboratories. The current curriculum determine that students required to meet some competencies as subject's minimum completion. The competency reached not only from conventional class but also 
from assignments, discussion, independent experiment and some activities that take place outside of school. Virtual laboratory is considered important by the school so students may perform experiment activity such as experiment in physical laboratory. There are two important components in virtual laboratories, i.e. simulation and animation. Simulation aims to describe the real environment in a system. Through simulation the students can experiment by replacing parameter's value so experiment produce different behavior. The different behaviors are then displayed through animation. These experimental results may also automatically recorded by the system and taken as report.

The goals of this study are; first, design and develop a virtual laboratory application to help creating and managing independent and interactive experiment activity process; second, accommodates student's experiment independency, which is limited by the number of learning hours, the number of meeting, and inadequate equipment for experiment; third, create an innovative learning system in order to improve the quality of students as a reflection of learning independence.

\section{VIRTUAL LABORATORY}

Laboratory usually defined as: 1). place equipped for experimental study in science or for testing and analysis; 2). place that provides an opportunity for experiment, observation, or practice in the field of study, or 3). academic periods set aside for laboratory work.

A virtual laboratory is defined as an interactive environment to create and conduct simulation experiments: a playground for experimentation. It consists of domain dependent simulation program, experimental units called objects that include data files, a tool that operates on objects, and reference books [5].

Virtual laboratory is a system that can be used to support a system that runs a conventional laboratory. These laboratory are usually called the Virtual Laboratory or V-Lab. Hopefully, this virtual laboratory may provide an opportunity to students, especially to do experiment with or without access to the Internet so that students do not need to be present to participate in an experiment at the laboratory. This kind of learning will be effective because students can learn by themselves actively without an instructor or assistant, unlike currently running system. Web based display format considered enough to help students to follow the experiment independently [6].

\subsection{Virtual Laboratory to Support Learning Process}

Virtual environment, called virtual laboratory, varies from static web pages with video and text to dynamic pages with sophisticated environments, such as collaborative authoring [7], video on demand, virtual meetings, and many other features. This virtual laboratory could also allow remote access to measurement instruments, video cameras, microphones, electrical and mechanical circuits, chemical reactions, biological experiments, and so on.

The diversity of models and structures for virtual lab is very wide and varies according to the nature of the projects examined, objectives, and the technology involved. Motivation for implementing virtual labs including, but not limited to [7]:

1. Limitations on resources and laboratory space in the real world. This type of limitation can cause delays in students' learning activities, who may face a situation where they have to compete or to wait given the availability of resources. Other than the fact that an experiment may be interrupted before the conclusion achieved because the required resource are divided.

2. The possibility of sharing equipment is usually expensive.

3. Stimulus for collaborative research or work in groups independent of their physical distance.

4. The existence of the learning environment outside school, which allows students to participate or develop their own project together with other students in their spare time.

5. The possibility of developing a variety of experiments in different locations.

6. Remote supervision and intervention in dangerous experiments, thus helping to prevent accidents.

7. Access and control of remote equipment.

\subsection{Virtual Laboratory Type}

Virtual laboratories can be divided into two main types, namely simulator based laboratory and equipment based on real hardware laboratory in either 2-D or 3-D. The first type is based on a set of software model that is the object or system in a certain level of abstraction. The only problem here is with the accuracy of the simulator behavior. Very often the real object is different from their abstract models. This is because the abstract model is developed to be simple and to help students to understand the basics. Most of them can not represent all of the features of the object simulation. The second type of virtual labs that cover most of the quality of the first kind and allow this approach to the classics. In every classroom there are shelves with equipment that cannot be used for distance learning and inaccessible to students all the time. So combine the classic with the modern learning allowing remote access to real equipment may improve the flexibility of teaching process and real laboratory usage. Using software and network technology, equipment connected to access [8].

\section{APPLICATION DEVELOPMENT METHOD}

Computer-Based System Engineering Method is used in the development of virtual laboratory application. The method is based on the principal of software engineering through the development steps according to System Development Life Cycle (SDLC). SDLC consists of several steps, i.e. analysis, design, implementation, testing and evaluation. Those steps may be done in overlap and cyclical way.

Generally, the virtual laboratory architecture is built upon three main components [9]:

1. End-user application environment. It provides experiments based on specific scientific domain. Enduser application run the experiment under this components. As far as the end-user concerns, it is the virtual laboratory.

2. Middleware. Middleware works between the higher level client side application and the lower level distributed computing facilities. The middleware, binds with the front-end interface, works to enable the virtual laboratory users to define and execute their experiments.

3. Distributed computing environment. Distributed computing environment provides computing and communication resources at the virtual laboratory in a more efficient utilization. 


\subsection{Requirement Analysis}

Requirement analysis is held to obtain input, for designing purpose, in the form of a data flow diagram of the currently developed application. The diagram contains systems engineering requirements which include software, hardware, servers and networks that are required in the design and implementation of the virtual laboratory applications.

\subsection{The Design of Virtual Laboratory Applications}

The design phase use the output of requirements analysis. This phase will result in the virtual laboratory application specification and design. The application has 3 types of users, student, teacher, and system administrators. Learning scenario in general used on application is as follow:

1. Student registers to the application. Successful registration will give the student a set of username and password.

2. Student may log into the application using the given username and password. User will receive a session ID If the login attempt is successful. Session ID acts as unique identity of each learning session. The session ID is used every time the student enters the application and remains active until the student decide to log out.

3. After logged in, the student will meet experiments list offered by the application. Student chooses one from the offered experiments. Students may add an experiment to their followed experiment list by the folowing condition; their request for the experiment is approved or the experiment is under free to follow category (means that approval of the application or pre-test is not required).

4. Student may choose one of the experiment from the followed experiment list. Under the chosen experiment, student may download experiment material from the server, store it in their computer and start to experiment.

5. Student may follow the final examination to test the level of understanding. If the student passed the exam, passing grade/assessment data will be included into student portfolio.

6. During the experiment, student may discuss with fellow student who followed the same experiment or with the teacher by sending text questions or comments to the forum.

7. Student who completed a learning session may log out from the application. The process will reset the registered session ID in the application.

Based on the processes from the previous section, the application requires a connection to the server only on some occasion, i.e. $\log$ in, view experiment list and server content, download content, conducting experiment, send answer and send message.

\subsection{Design Implementation}

Virtual laboratory applications is built using PHP and Action Script as programming script that runs on Apache web server. Procedures that determined from the design phase are coded and documented. MySQL database is used to store processed data.

\section{RESULT AND DISCUSSION}

\subsection{Design Implementation}

Since virtual laboratory is a web-based application, the system specification include server-side specification and client-side specification.

\section{Server-Side Specification}

The implementation of virtual laboratory is hosted on third party provider and can be accessed via http://vlsma.net. Table 1 shows complete information about the server side specification.

Table 1. Virtual laboratory Server Specification

\begin{tabular}{|c|c|c|}
\hline No. & Specifications & Description \\
\hline 1 & Domain & http://vlsma.net \\
\hline 2 & Web Hosting & http://idwebhost.com \\
\hline 3 & The Storage Capacity & 2 GB \\
\hline 4 & Bandwith & 50 GB per month \\
\hline 5 & $\begin{array}{c}\text { Platform's Operating } \\
\text { System }\end{array}$ & CentOS Server \\
\hline 6 & Web Server & Apache \\
\hline 7 & Database & MYSQL \\
\hline
\end{tabular}

\section{Client-Side Specification}

Client may access the virtual laboratory application use any web browser which supports Flash Player with suggested minimum screen resolution $1024 \times 768$. In this research, the application is accessed via Google Chrome web browser.

\subsection{Application Implementation Result}

The required files in virtual laboratory application are hosted to the web hosting provider. The pages of virtual laboratory application consists of three main view categories, student view, teacher view and administrator view.

\section{Student View Pages}

Student view pages shows pages for user of virtual laboratory application that acts as student. The student may access the virtual laboratory via web browser.

First page of virtual laboratory application showed to the student is login page. Student may log in to the application by supplying the required username and password. Unregistered user may apply to the administrator for registration. Login page are shown in figure 1 .

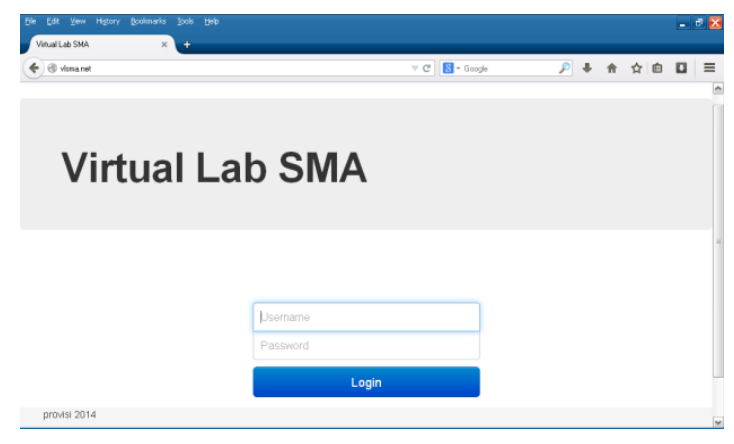

Fig 1: Login page

Successfully logged in, student headed to the student main page. The main page shows courses followed by the student. Student may choose the available option to access other pages such as contents, news, discussions, assignments, exams and exam results. Using logout button, students may exit the virtual laboratory application. Student main page and menu choice shown in Figure 2. 




Fig 2: Student Main Page

Experiment page is the page that contains the learning content if the form of flash interactive multimedia, so that students can do the simulation, as shown in Figure 3.

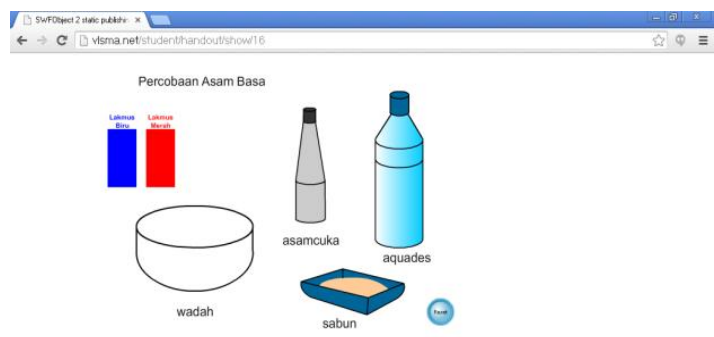

Fig 3: Experiment Page

2. Teacher View Pages

Teacher view pages are pages for teacher to manage courses, such as enroll students, upload content, make news/announcements, manage discussion, make assignment, make exam and see students' exam result. Teachers may access the virtual laboratory via web browser after logged in.

Successfully logged in, teacher headed to the teacher main page. The main page shows courses managed by the teacher with the following options, content, news, discussions, assignments, exams and exam results. Using logout button, teachers may exit the virtual laboratory application. Teacher main page and menu choice shown in Figure 4.

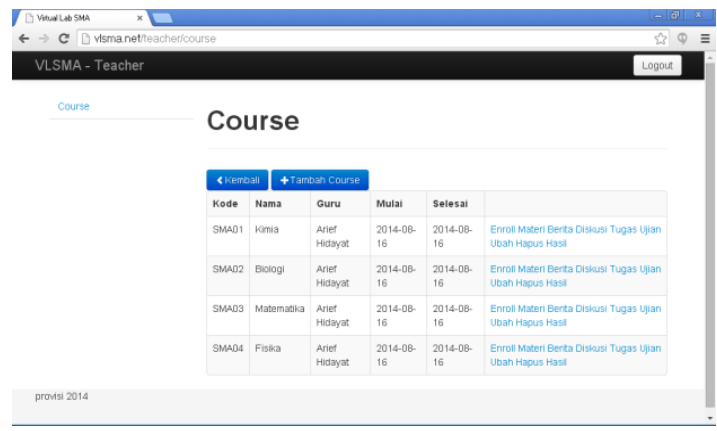

Fig 4: Teacher Main Page

Teacher use experiment upload page to upload content in the form of interactive multimedia for every chapter/topic in the course. The students may watch and download them. Experiment upload page is shown in Figure 5.

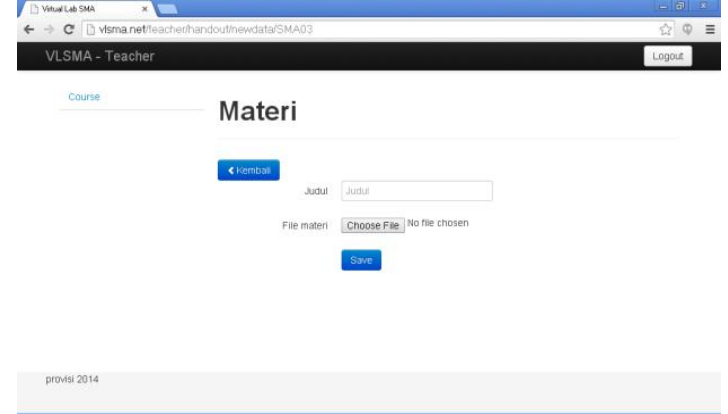

Fig 5: Experiment Upload Page

3. Administrator View Pages

Administrator view pages are pages for administrator to manage users and courses. Administrator access virtual laboratory application via web browser in the computer after logged in

Successfully logged in, administrator headed to the administrator main page. In the page, there are two options i.e. user management and course management. Using logout button, administrators may exit the virtual laboratory application. Teacher main page and menu choice shown in Figure 6.

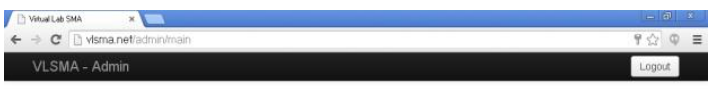

Halaman Admin


Fig 6: Administrator Main Page

Administrator use "add user" page to add user for the virtual laboratory application as well as the user's authority. There are three types of authority, i.e. administrator, teacher or student. Add user page is shown in Figure 7.

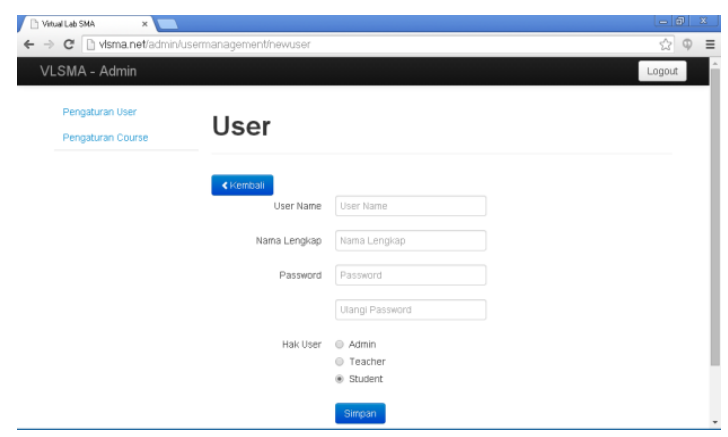

Fig 7: Add User Page

Administrator use "add course" page to add course that will be delivered in the virtual laboratory application. Administrator also need to supply the teacher responsible for the course. as well as the user's authority. Add course page is shown in Figure 8. 


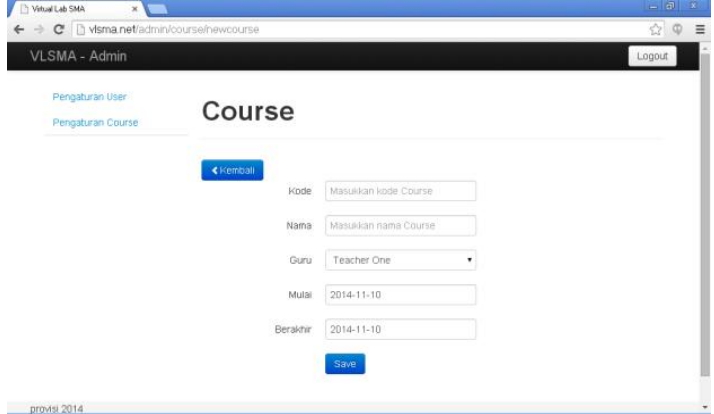

Fig 8: Add Course Page

\subsection{Application Testing}

This virtual laboratory application is tested under black box method. Black box test is application program test based on application program functionality. The purpose of the black box method is to find a malfunction in the application.

Alpha-test trial is held to determine the virtual laboratory application ability to run on mobile devices such as cellphone, PDA or smart phone. Test is held against every function / submodule of the application program. Feedback obtained by creating a trial class of 40 students which are told to try the virtual laboratory application. Results obtained from the feedback is almost $90 \%$ say of the students say the virtual laboratory applications is acceptable and easy to use. Table 2 shows summary of virtual laboratory's ease of use.

Table 2. Summary of virtual laboratory's ease of use

\begin{tabular}{|l|c|c|}
\hline \multicolumn{1}{|c|}{ Questions } & Agree & Disagree \\
\hline $\begin{array}{l}\text { I can use this application without } \\
\text { any guidance or minimal } \\
\text { guidance }\end{array}$ & 38 & 2 \\
\hline $\begin{array}{l}\text { I can understand objective of the } \\
\text { application }\end{array}$ & 40 & 0 \\
\hline $\begin{array}{l}\text { The instructions and prompts are } \\
\text { helpful }\end{array}$ & 38 & 2 \\
\hline $\begin{array}{l}\text { The application always did what I } \\
\text { was expected }\end{array}$ & 37 & 3 \\
\hline I can easily view my experiments & 37 & 3 \\
\hline $\begin{array}{l}\text { The application has a very } \\
\text { attractive presentation }\end{array}$ & 37 & 3 \\
\hline $\begin{array}{l}\text { This application can help me to } \\
\text { do experiments on my own }\end{array}$ & 36 & 4 \\
\hline $\begin{array}{l}\text { This application help me to } \\
\text { recognize my strength and } \\
\text { weakness of the subject }\end{array}$ & 36 & 4 \\
\hline $\begin{array}{l}\text { I can take experiments at any time } \\
\text { and place I like }\end{array}$ & 37 & 3 \\
\hline $\begin{array}{l}\text { Working with this application is } \\
\text { satisfying }\end{array}$ & & \\
\hline
\end{tabular}

\section{CONCLUSION}

Based on the results and discussion, some conclusion regarding the virtual laboratory application are made. The conclusions are 1). virtual laboratory applications can be used to manage experiment virtually, 2). virtual laboratory applications can be used to upload, read, make an experiment virtually and download experiment content, 3 ). teacher may use the application to make online announcement to the students, 4). students may upload their assignment task for the teacher using the application, and 5).teacher may use the application to evaluate the students in the form of quiz or exam. Future work of this research are additional feature that needed by user such as guest book, record pages accessed by users and interaction with teacher in the form chating. Another enhancement may include improving virtual appearance in virtual laboratory to give better experience, allowing data compression which reduce the size of data accessed by user without sacrifice any content.

\section{ACKNOWLEDGMENTS}

Researchers would like to thank to the Ministry of Education and Culture - General Director of Higher Education (DIKTI) which provide fund for this research.

\section{REFERENCES}

[1] Hidayat A, Purwanto H. 2013. "Designing Application of M-Learning based on Content Management System". International Journal of Computer Applications 80(7):710, October 2013

[2] Aryana, dkk. 2007. "Pengembangan Peta Pikiran Untuk Peningkatan Kecakapan Berpikir Kreatif Siswa”. Jurnal Universitas Pendidikan Ganesha. Makasar.

[3] Munandar, U. 2009. Pengembangan Kreativitas Anak Berbakat. Jakarta: Rineka Cipta.

[4] Slameto. 2003. Belajar dan Faktor-faktor yang Mempengaruhinya. Jakarta : Rineka Cipta

[5] Albu, M.M.; Holbert, K.E.; Heydt, G.T.; Grigorescu, S.D.; Trusca, V., 2004. Embedding Remote Experimentation In Power Engineering Education," Power Systems, IEEE Transactions on, vol.19, no.1, pp.139, 143, Feb. 2004 doi 10.1109/TPWRS.2003.821020

[6] Puspita, Rani. 2008. Sistem Informasi Aplikasi Virtual Lab Pada Laboratorium Sistem Informasi Universitas Gunadarma. Proceeding, Seminar Ilmiah Nasional Komputer dan Sistem Intelijen (KOMMIT 2008) Auditorium Universitas Gunadarma, Depok, 20-21 Agustus 2008. ISSN : 1411-6286.

[7] Emigh, W., \& Herring, S. C. 2005. Collaborative authoring on the Web: A genre analysis of online encyclopedias. In Proceedings of the IEEE Hawaii International Conference on System Sciences, 4 (pp. 99.1).

[8] Orlin Tomov. 2008. Virtual Labs with Remote Access to a Real Hardware Equipment in the Computer Systems Education. In Proceedings of the 9th International Conference on Computer Systems and Technologies and Workshop for PhD Students in Computing (CompSysTech '08), Boris Rachev and Anger Smrikarov (Eds.). ACM, New York, NY, USA, , Article 79. DOI $=10.1145 / 1500879.1500965$ http://doi.acm.org/10.1145/1500879.1500965

[9] H Afsarmanesh, E.C Kaletas, A Benabdelkader, C Garita, L.O Hertzberger. 2001. "A reference architecture for scientific virtual laboratories". Future Generation Computer Systems Journal, Volume 17, Issue 8, Pages 999-1008. 